\title{
Miscellany
}

\section{Mental Health Workforce Review}

The Sainsbury Centre for Mental Health has launched a wide-ranging Mental Health Workforce Review to assess the staffing problems facing mental health services in England. The review, which is due for completion by early 2000 . will examine the current and future supply of mental health staff, identify problems affecting their recruitment and retention and make recommendations on the specific steps required to secure an adequate supply of mental health staff to meet future needs. The Sainsbury Centre for Mental Health would like to hear from those who are commissioning or providing mental health services, and are facing or have solved staff supply problems. Areas of particular interest are as follows: information on existing or expected future supply problems, approaches to solving supply problems (highlighting the learning points) and approaches to recruitment and retention. Further details can be obtained from Heather Harper, The Sainsbury Centre for Mental Health, 134-138 Borough High Street, London SEl 1LB (telephone: 0171827 8355, fax: 0171 403 9482, e-mail: heather.harper@scmh.org.uk).

\section{New internet service for doctors}

The College is collaborating with Doctors.net.uk, a new internet service run by doctors for doctors, to make available, free of charge, internet access to PsychLIT, a bibliographic database which many members will know is more comprehensive for psychiatry and psychology than Medline. Doctors.net.uk offers other important benefits to subscribers, including free e-mail addresses, discussion forums and on-line library resources. Doctors.net.uk is run by practising doctors according to strict professional standards. To join the service simply go to http://www.Doctors. net.uk. You will need your GMC details to join. PsychLIT should be available shortly. For further details contact Dr Tom Sensky, Reader in Psychological Medicine, Imperial College School of Medicine, West Middlesex University Hospital, Isleworth, Middlesex TW7 6AF (telephone: 0181 321 5179, fax: 01812449917 , e-mail: t.sensky @ic.ac.uk).

\section{Expert witness - new scheme}

The Society of Expert Witnesses has introduced a new scheme to put aspiring or novice expert witnesses in touch with its more experienced members. The 'mentor' scheme allows novice expert witnesses to join the Society as associate members which will enable them to request to be introduced to a more experienced member, within the same area of expertise, who is willing to share his or her practical knowledge. For further information about the Society and its mentor scheme contact: The Society of Expert Witnesses, PO Box 345, Newmarket CB8 7TU (telephone: 0345 023014, fax: 01638 560924, e-mail: 100014.1530@compuserve.com).

\section{What Children Remember video}

The National Council for Family Proceedings have produced a video entitled What Children Remember. Following a workshop given by Professor Stephen Ceci, of Cornell University at the National Council for Family Proceedings late last year, the video is based on Professor Ceci's 10 years of research and offers an analysis of what children can remember, as well as advice to lawyers, social workers, psychologists, psychiatrists and other professionals who have to talk to children, question them and get them to tell the truth. Copies of the video are obtainable, at a cost of $\$ 47$ inclusive of VAT, postage and packaging, from the National Council for Family Proceedings. University of Bristol, Wills Memorial Building, Queens Road, Clifton, Bristol BS8 1RJ (telephone: 0117954 5381, fax: 0117925 1870, e-mail: Jim.Lawson@bris.ac.uk).

\section{New publications}

West London Health Estates, an agency of Ealing, Hammersmith \& Hounslow Health Authority, have published a report commissioned by the Health Facilities Management Association entitled Community Based Mental Health Facilities - Including People with a Learning Disability: Safety and Security by Design. The objective of the project leading to the report. and the resulting publication can be summarised as being to produce national guidance, focusing on safety and security in community-based mental health facilities which sets out descriptions of the various dependency levels within each of the main mental health categories, and guidance on technical/design good practice in respect of safety and security. The report is available from the College library. Copies can be purchased at $£ 60$ each by contacting WLH estates, West Ealing 
House, 2 St James Avenue, London W13 9DJ (telephone: 0181893 0700, fax: 01818409362 , e-mail: wlh@online.rednet.co.uk).

MIND Publications have launched a new booklet entitled Understanding Dual Diagnosis. The booklet is part of the charity's award winning series and looks at the symptoms of dual diagnosis, the effects of street drugs on mental health and the possible interactions between psychiatric drugs and illicit drugs. The guide also contains details of further reading and a list of useful organisations. Priced at $£ 1$ plus a $38 p$ A5 sized SAE. Copies are available from MIND Publications, 15-19 Broadway, London E15 4BQ (telephone: 0181 519 2122).
A new title from Butterworth-Heinemann is Child Protection and Adult Mental Health, edited by Anthony Douglas and Amy Weir. Placing an emphasis on effective professional, interdisciplinary collaboration, this practical book offers clear guidance to those at the sharp end of child protection, whether in the community or institutional setting. It aims to show how professionals can bridge the gap between the conflicting needs of a child and its parents with mental health problems. Available at $£ 16.99$ (ISBN: 07506 29045) from the Customer Services Department, Heinemann Publishers Oxford, PO Box 382, Halley Court, Jordan Hill, Oxford OX2 8RU (telephone: 01865 314301, fax: 01865 314029).

\section{PATIENTS AND CARERS AND COLLEGE ACTIVITIES CAN YOU HELP?}

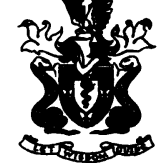

The College is considering setting up a database of patients and carers who might contribute to College Committees, working parties and the Changing Minds: Every Family in the Land Campaign.

Although the college has a very active 'Patients and Carers' Liaison Group, which includes representatives from the main mental health patients and carers organisations such as National Schizophrenia Fellowship, Mindlink, Manic Depression Fellowship, the External Affairs department would be interested to hear from any members of the College who may know of patients and carers who would be interested in getting involved in college activities.

Please forward any suggestions to Deborah Hart, Head of External Affairs e-mail: dhart@rcpsych.ac.uk

Royal College of Psychiatrists. 17 Belgrave Square, London, SWIX 8PG. Tel: $017 \mid 2352351$ extension 127. Fax: $017 \mid 245$ 1231 